\title{
RNase Activity in Erythroid Cell Lysates
}

\author{
EDWARD R. BuRKa \\ From The Cardeza Foundation for Hematologic Research, Department of \\ Medicine, Jefferson Medical College, Philadelphia, Pennsylvania 19107
}

A B S T R A C T The characteristics of degradation of reticulocyte ribonucleic acid (RNA) and ribosomes were studied in a whole erythroid cell lysate system. The process followed Michaelis-Menten kinetics, and indicated that RNA degradation in the erythroid cell is mediated by an enzyme previously isolated from reticulocyte hemolysates. Erythroid cell RNase activity had a temperature optimum of $50^{\circ} \mathrm{C}$, a $\mathrm{pH}$ optimum of 7.0 , was not energy dependent, was heat labile at physiologic $\mathrm{pH}$, and was inhibited by $\mathrm{Mg}^{++}, \mathrm{Ca}^{++}$, and exposure to bentonite and deoxycholate. Free sulfhydryl groups were not essential for RNase activity. Of the substrates occurring naturally within the erythroid cell, isolated ribosomal RNA was most susceptible to the action of the enzyme, intact ribosomes least susceptible, and transfer RNA intermediate between them. Natural substrates were degraded completely to nucleotides in cell lysates. Competitive inhibition studies indicate that one enzyme system is capable of degrading both RNA and ribosomes, although the existence of more than one enzyme has not been excluded. Erythroid cell lysates quickly broke down polyribosomes into single ribosomes. The more rapid degradation of ribosomes, as compared with transfer RNA, which occurs in vivo, as opposed to findings in vitro, suggests that there is a special intracellular mechanism responsible for ribosome degradation in the maturing erythroid cell.

\section{INTRODUCTION}

Maturation of the mammalian erythroid element is accompanied by a decrease in RNA content of the cell (1). Degradation is the sole means of altering the cell content of RNA in the late stages of erythroid cell maturation, because the mammalian reticulocyte lacks the capacity to synthesize RNA (2). The maturing erythroid cell, therefore, offers a unique opportunity to study the relationship between cell maturation and degradation of RNA. Farkas and Marks have demonstrated that an

Received for publication 21 April 1969 and in revised form 26 May 1969.
RNase extracted from the soluble fraction of rabbit reticulocytes is capable of degrading a natural substrate, reticulocyte RNA, and of attacking reticulocyte polyribosomes (3). Other attempts to characterize the RNase of erythroid cells (4-10) have given contradictory reports as concerns $\mathrm{pH}$ optima, substrate specificity, inhibitory substances, and location within the cell. Thus far, it has not been conclusively demonstrated that any of the isolated enzymes are responsible for degradation within the cell.

Clear understanding of the relationship between RNA degradation and erythroid cell maturation requires knowledge of events as they occur within the cell. A previous report has outlined features of RNA degradation in intact erythroid cells (11). The present study, which utilizes an in vitro erythroid cell lysate system which approximates the characteristics of degradation of natural substrates in vivo, further defines aspects of erythroid RNA degradation as it occurs in a physiologic environment. The characteristics of the process indicate that the RNase isolated by Farkas and Marks (3) is responsible for RNA degradation in the erythroid cell. Natural substrates have been found to differ in their susceptibility to degradation. In contrast to the finding in the intact cell that ribosomes are more susceptible to degradation than is transfer RNA (11), in the lysate system ribosomes are more resistant to degradation than in transfer RNA. This suggests that a specific mechanism for ribosome degradation must be present in the intact cell.

\section{METHODS}

Isolation of cells and preparation of cell lysates. Peripheral venous blood was obtained from normal New Zealand white rabbits or from animals with a reticulocytosis induced by four daily subcutaneous injections of a $2.5 \%$ solution of phenylhydrazine hydrochloride (12). The blood was collected in heparinized syringes 3 days after the final injection and. immediately placed in an ice bath. All subsequent procedures were done at $0^{\circ}-4^{\circ} \mathrm{C}$. The cells were separated by centrifugation and washed twice with 10 volumes of 310 milliosmolar phosphate buffer, pH 7.4. After each wash the buffy coat was removed by aspiration. Cells from which ribosomes were to 
be prepared were washed in $0.9 \%$ sodium chloride solution which contained $1.5 \times 10^{-3} \mathrm{M}$ magnesium chloride.

It was necessary to ensure that the cells were not contaminated with a ribonuclease present in blood plasma. After separation of the red cells by centrifugation ribonuclease activity was determined in the plasma and in the buffer used to subsequently wash the cells. In an animal with a hematocrit of approximately $20 \%$ at the time of cell collection the total nuclease activity in the plasma was roughly twice that found in the sedimented cells. Packed cells obtained in this manner are contaminated to an extent of less than $3 \%$ with plasma (13). The supernatant fluid following the second wash contained only a trace of nuclease activity, and none was present in the supernatant from the third wash. Therefore, twice-washed cells were considered to be free of exogenous nuclease and were routinely used in the assay system to be described.

Cells were lysed by addition of four volumes of hypotonic solution, either $7.37 \times 10^{-3} \mathrm{M}$ sodium phosphate buffer, $\mathrm{pH}$ 7.4 , distilled water, or a solution of $1.5 \times 10^{-3} \mathrm{M}$ magnesium chloride in $1 \times 10^{-8} \mathrm{M}$ Tris, $\mathrm{pH} 7.5$ (solution A). Membranefree hemolysates were prepared by centrifugation at $17,300 \mathrm{~g}$ for $10 \mathrm{~min}$.

Preparation of ribosomes and $R N A$. Erythroid cell RNA and $\mathrm{RNA}^{-{ }^{2} \mathrm{P}}$ were prepared and purified by the phenol method as previously described (14). After dialysis for $18 \mathrm{hr}$ at $4^{\circ} \mathrm{C}$ the $\mathrm{RNA}$ was stored at $-20^{\circ} \mathrm{C}$ in $0.1 \mathrm{M}$ sodium acetate buffer, $\mathrm{pH}$ 5.1. Ribosomes were prepared by ultracentrifugation of membrane-free hemolysates at $226,000 \mathrm{~g}$ for $90 \mathrm{~min}$. Ribosomes were stored in solution $\mathrm{A}$ at $-20^{\circ} \mathrm{C}$ until used, or ribosomal RNA was prepared from them. Soluble RNA was prepared from the $226,000 \mathrm{~g}$ supernatant. This fraction has previously been shown to be free of significant contamination with ribosomal RNA (15). Sucrose density gradient centrifugation was carried out as previously described (12).

Analytical methods. Hemocytometry, ennumeration of reticulocytes, and determination of hematocrit were done by standard methods. RNA in erythroid cells was extracted and determined as previously described (16). Nonerythroid elements of the blood have been shown not to significantly affect the results of these determinations (16).

Assay of ribonuclease activity. Ribonuclease activity was determined at $37^{\circ}$ in a 1 or $2 \mathrm{ml}$ system consisting of whole hemolysate or membrane-free hemolysate, $7.37 \times 10^{-3} \mathrm{M}$ phosphate buffer, and an appropriate ${ }^{22} \mathrm{P}$-labeled substrate. The substrates used were total RNA, ribosomal RNA, transfer RNA, or ribosomes isolated from rabbit reticulocytes and added in amounts closely approximating the actual concentration of RNA in reticulocytes (15). At the initiation and conclusion of incubation ice-cold trichloracetic acid (TCA) was added to a final concentration of $5 \%$ in duplicate assay tubes. The precipitated, acid-insoluble RNA and protein were sedimented by centrifugation at $17,000 \mathrm{~g}$ for $10 \mathrm{~min}$. An aliquot of the clear supernatant, containing acidsoluble RNA breakdown products, was placed in a counting vial for determination of radioactivity. When additions to the assay system were made, appropriate controls were obtained at the initiation and conclusion of incubation by adjusting the amounts of reagents and additives in all tubes to identical concentrations. During $4 \mathrm{hr}$ in phosphate buffer at temperatures up to $90^{\circ} \mathrm{C}$ native $\mathrm{RNA}-{ }^{a 2} \mathrm{P}$ did not break down into acid-soluble fragments.

Determination radioactivity. ${ }^{22} \mathrm{P}$ radioactivity in TCA extracts, plasma, hemolysates, and substrate material was determined by pipetting $0.2-0.5 \mathrm{ml}$ of the solution directly into $10 \mathrm{ml}$ of Bray's solution (17). The vials were counted

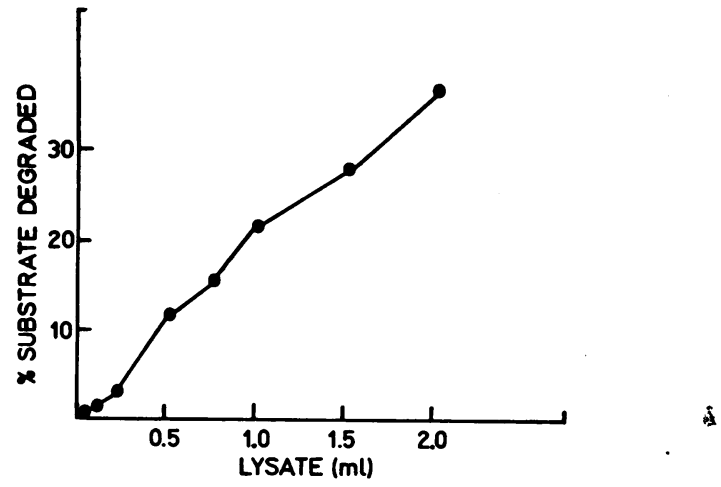

FIgURE 1 The relationship between the rate of RNA degradation and the amount of whole lysate in the assay system. The substrate used was $0.15 \mathrm{mg} / \mathrm{ml}$ of total reticulocyte RNA- ${ }^{32} \mathrm{P}$ in a $2.0 \mathrm{ml}$ system containing appropriate amounts of $7.37 \times 10^{-8} \mathrm{M}$ phosphate buffer, $\mathrm{pH} 7.4$, and whole lysate prepared in the same buffer. Destruction of RNA during a $2 \mathrm{hr}$ incubation at $37^{\circ} \mathrm{C}$ is reported as per cent of total substrate degraded.

in a Packard liquid scintillation counter with an efficiency of more than $95 \%$. In all cases sufficient counts were accumulated to reduce counting error to less than $3 \%$.

Materials. Rabbits were obtained from commercial sources. All chemicals used were reagent grade. Liquified phenol and bentonite were obtained from the Fisher Scientific Company, King of Prussia, Pa. Bentonite was prepared as described by Fraenkel-Conrat, Singer, and Tsugita (18). Carrier-free ${ }^{82} \mathrm{P}$ was obtained from Tracerlab Div., Laboratory for Electronics, Inc.

\section{RESULTS}

$R N A$ degradation in whole cell lysates. The initial studies determined if ribonuclease activity was present in cell lysates, and if so, whether it resembled that present in intact cells. The characteristics of RNA degradation in whole cell lysates, determined by assaying RNA at the beginning and conclusion of a 2 or $4 \mathrm{hr}$ incubation at $37^{\circ} \mathrm{C}$ was compared with that previously observed during incubation of whole cells (11). The rate of total RNA degradation in six studies in the intact cell was $3.9 \pm 2.5 \% / \mathrm{hr}(11)$, comparable with the rate observed in the whole cell lysates, $3.4 \pm 1.7 \% / \mathrm{hr}$. Thus, RNA catabolism does proceed in whole cell lysates at a rate similar to that in the intact cell. Other similarities between RNA catablism in the intact cell and in whole cell lysates, documented below, included absence of RNA degradation at $0^{\circ} \mathrm{C}$, a temperature optimum of $50^{\circ} \mathrm{C}$, and the lack of significant inhibition of RNA degradation by fluoride, cyanide, or iodoacetate.

RNA degradation in the assay system was proportional to the amount of whole lysate added to the system over a wide range (Fig. 1). The rate of degradation of RNA by whole cell lysates at $37^{\circ} \mathrm{C}$ was linear for the initial $30 \mathrm{~min}$ of incubation, and thereafter decreased (Fig. 2). 


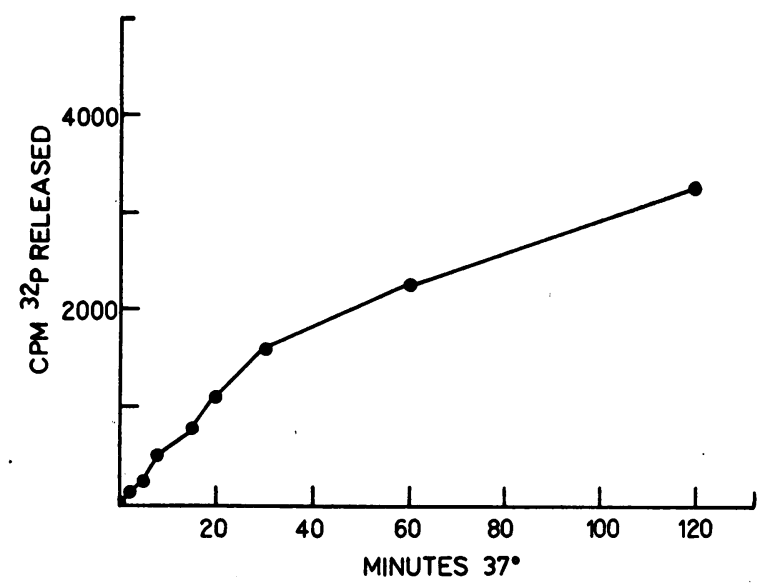

FIgURE 2 The rate of degradation of reticulocyte RNA by whole lysate during incubation at $37^{\circ} \mathrm{C}$. Acid-soluble degradation products of total reticulocyte $\mathrm{RNA}-{ }^{22} \mathrm{P}$ were determined at intervals in aliquots of the assay system described for Fig. 1.

RNase activity was present in hemolysates prepared from blood with a high proportion of reticulocytes and from normal blood. Activity in normal blood, however, was lower, per unit of hemoglobin, than in blood with a reticulocytosis. RNase activity was present in whole cell lysates and in membrane-free hemolysates. Removal of the cell membranes by centrifugation did not significantly alter the characteristics of RNase activity in the hemolysates.

$p H$ and temperature optima. The $\mathrm{pH}$ optimum for the rate of RNA degradation was 7.0 in both phosphate and Tris buffer and fell off sharply as the $\mathrm{pH}$ was increased (Fig. 3 ). The stability of RNase activity in the lysates (see below) did not differ over the $\mathrm{pH}$ range tested during a $2 \mathrm{hr}$ incubation. ${ }^{2}$ The effect of temperature on RNA degradation in whole lysates was similar to that observed in the intact cell (11), as shown in Fig. 4. No degradation was observed at $0^{\circ} \mathrm{C}$ and the rate of degradation was maximal at $50^{\circ} \mathrm{C}$, although assays were usually carried out at $37^{\circ} \mathrm{C}$. Degradation was not completely abolished at temperatures of $90^{\circ} \mathrm{C}$.

Requirement for energy. Since the degradation of RNA in whole lysates did not occur at $0^{\circ} \mathrm{C}$ investigations were carried out to determine if energy was required for the reaction. The addition to the assay system of an energy generating system consisting of final concentrations of $1 \times 10^{-8} \mathrm{M}$ adenosine triphosphate (ATP), $2 \times 10^{-4}$ M guanosine triphosphate (GTP) $5 \times 10^{-8} \mathrm{M}$ phosphoenol pyruvate, and $100 \mu \mathrm{g} / \mathrm{ml}$ of pyruvate kinase, did not enhance RNase activity. Inhibitors of either anerobic glycolysis, iodoacetate or fluoride, or oxidative glycolysis, cyanide, at concentration of $10^{-2}$ moles/liter

\footnotetext{
${ }^{1}$ Burka, E. R. Unpublished observations.
}

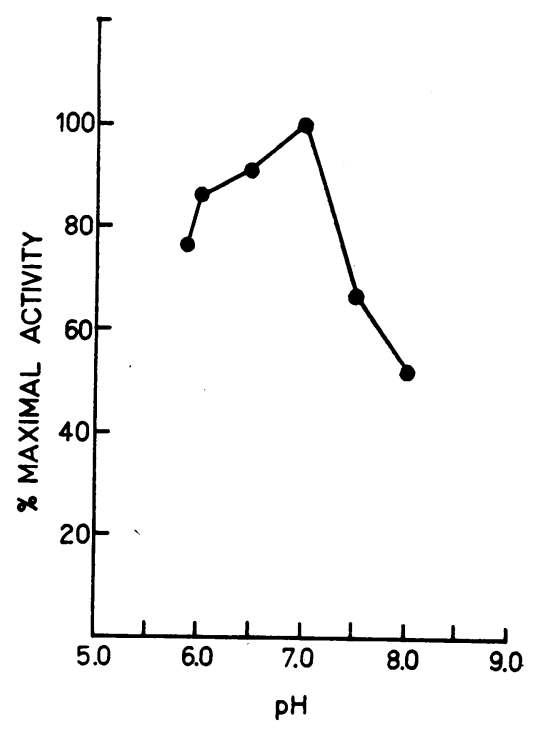

FIgURE 3 The relation of RNase activity in whole lysates to $\mathrm{pH}$. The lysates were prepared in $7.37 \times 10^{-8} \mathrm{M}$ phosphate buffer of the indicated $\mathrm{pH}$ and assayed for RNase activity under the conditions described for Fig. 1. A similar curve was noted in lysates prepared with $1 \times 10^{-3}$ M Tris buffer.

had only a minor effect on enzyme activity (Table I). These studies indicate that the degradation of RNA by erythroid cell RNase is not an energy-dependent process.

Requirement for ions. Lysates used in the assay system were routinely made in $7.37 \times 10^{-3} \mathrm{M}$ sodium phosphate buffer. As shown in Fig. 5, this buffer did not inhibit enzyme activity in concentrations up to 50 mmoles/liter. RNase activity did not have an absolute requirement for inorganic ions. Cell lysates made with

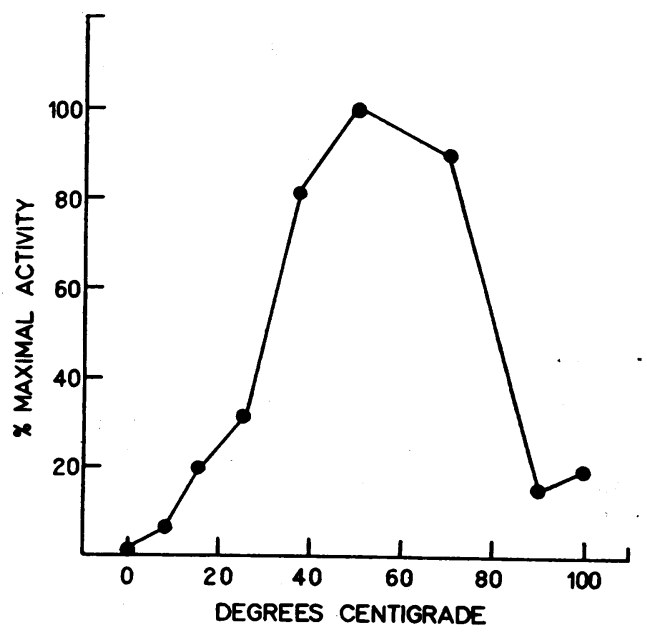

FIgURE 4 The relationship between RNase activity in whole lysates and temperature. Assay of whole lysates was carried out as described for Fig. 1 for $1 \mathrm{hr}$ at the indicated temperatures using $0.19 \mathrm{mg} / \mathrm{ml}$ total $\mathrm{RNA}-{ }^{82} \mathrm{P}$ as a substrate. 
distilled water, or dialyzed for $18 \mathrm{hr}$ against $1 \times 10^{-\mathrm{s}} \mathrm{M}$ ethylenediaminetetraacetate (EDTA), $\mathrm{pH} 7.5$, had activity between 82 and $112 \%$ of that in lysates made in phosphate buffer. Addition of either magnesium chloride or calcium chloride to the assay system caused a concentration-dependent loss of enzyme activity. This effect was due to the cations, as addition of similar concentrations of sodium chloride did not inhibit enzyme activity. Salt concentrations of 0.5 mole/liter abolished enzyme activity.

Effect of modifiers. The effects of known modifiers of enzyme activity are shown in Table I. Sodium deoxycholate was a strong inhibitor of RNase activity in whole cell lysates. The enzyme, like other ribonucleases, was adsorbed by bentonite. Addition and subsequent removal by centrifugation of either 4 or $12 \mathrm{mg}$ of bentonite $/ 10 \mathrm{ml}$ of whole lysate caused a decrease in RNA degradation to 78 and $11 \%$, respectively, of control activity. The addition of bentonite directly to the assay system also resulted in a loss of enzyme activity. The presence of $n$-ethylmaleimide or $p$-chloromercuribenzoate, agents which block sulfhydryl groups, was not inhibitory

TABLE I

Effect of Inhibitors on Whole Reticulocyte Lysate RNase Activity

\begin{tabular}{lcc}
\hline \multicolumn{1}{c}{ Inhibitor } & Concentration & $\begin{array}{c}\text { Activity } \\
\text { remaining }\end{array}$ \\
\hline \multirow{2}{*}{ Bentonite* } & $0.4 \mathrm{mg} / \mathrm{ml}$ & $\%$ \\
& $1.2 \mathrm{mg} / \mathrm{ml}$ & 78 \\
Deoxycholate & $0.1 \%$ & 11 \\
& $0.25 \%$ & 5 \\
Fluoride & $5 \times 10^{-3} \mathrm{M}$ & 91 \\
& $1 \times 10^{-2} \mathrm{M}$ & 91 \\
Cyanide & $5 \times 10^{-2} \mathrm{M}$ & 100 \\
& $1 \times 10^{-2} \mathrm{M}$ & 83 \\
Iodoacetate & $5 \times 10^{-2} \mathrm{M}$ & 94 \\
& $1 \times 10^{-2} \mathrm{M}$ & 88 \\
$n$-Ethylmaleimide & $1 \times 10^{-5} \mathrm{M}$ & 106 \\
& $1 \times 10^{-4} \mathrm{M}$ & 102 \\
& $2 \times 10^{-4} \mathrm{M}$ & 82 \\
p-Chloromercuribenzoate & $1 \times 10^{-5} \mathrm{M}$ & 108 \\
& $1 \times 10^{-4} \mathrm{M}$ & 98 \\
& $2 \times 10^{-4} \mathrm{M}$ & 100 \\
\hline
\end{tabular}

RNase activity in whole lysates was determined as described for Fig. 1 in the presence of the indicated substances. Degree of inhibition is expressed as the percent of enzymatic activity in the treated lysates as compared to that observed in a control assay.

* Added to whole lysates and then removed by centrifugation before assay for RNase activity.

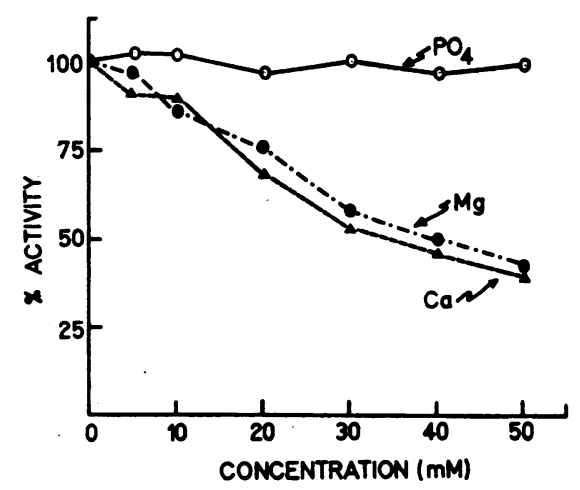

FIGURE 5 The effect of ionic strength on RNase activity in whole lysates. The lysates were prepared with distilled water and appropriate amounts of $1 \mathrm{M} \mathrm{Na}_{2} \mathrm{HPO}_{4} \mathrm{CaCl}_{2}$, or $\mathrm{MgCl}$ added to bring the system to the indicated molarity beforre assay of enzyme activity against a concentration of $0.08 \mathrm{mg} / \mathrm{ml}$ of total RNA- ${ }^{\infty}$ as described for Fig. 1. Results are expressed as per cent of degradation observed in the absence of the indicated ions.

at concentrations of less than $10^{-4}$ moles/liter. At greater concentrations $n$-ethylmaleimide caused a slight inhibition of enzyme activity. As might be expected from the relative lack of effect with these agents, the addition of reducing agents such as dithiothreitol or mercaptoethanol did not increase or prolong enzyme activity.

Stability of RNase activity. During incubation of whole lysates at $37^{\circ} \mathrm{C}$ RNase activity was progressively lost. The rate of loss was initially rapid, but decreased with the time of incubation. An average of $34 \%$ (range 14-44) of the initial activity remained after $22 \mathrm{hr}$ at

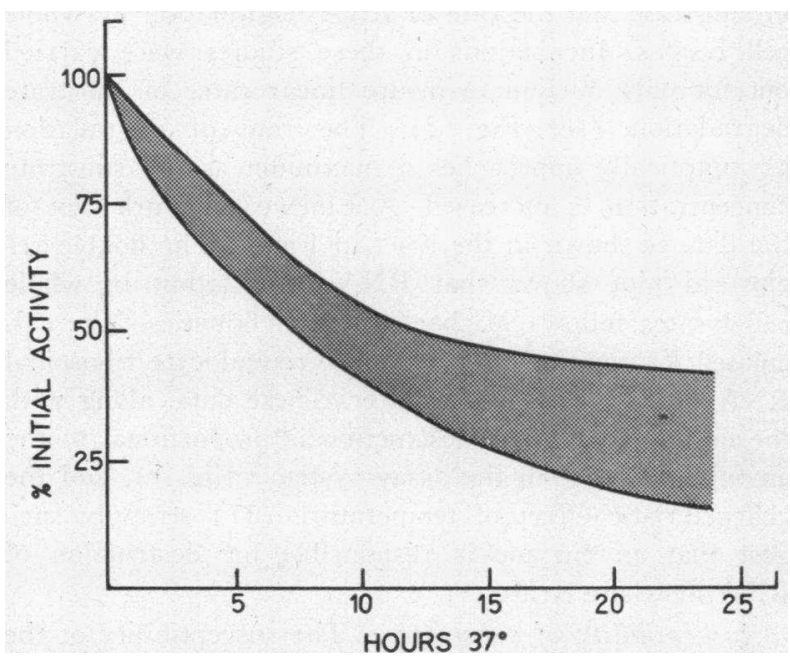

FIGURE 6 The decline in RNase activity in whole lysates during incubation at $37^{\circ} \mathrm{C}$. At intervals aliquots of the incubated lysate were assayed against a concentration of $0.19 \mathrm{mg} / \mathrm{ml}$ of total RNA- $P$ as described for Fig. 1. The shaded area represents the range of values observed in four separate studies. 


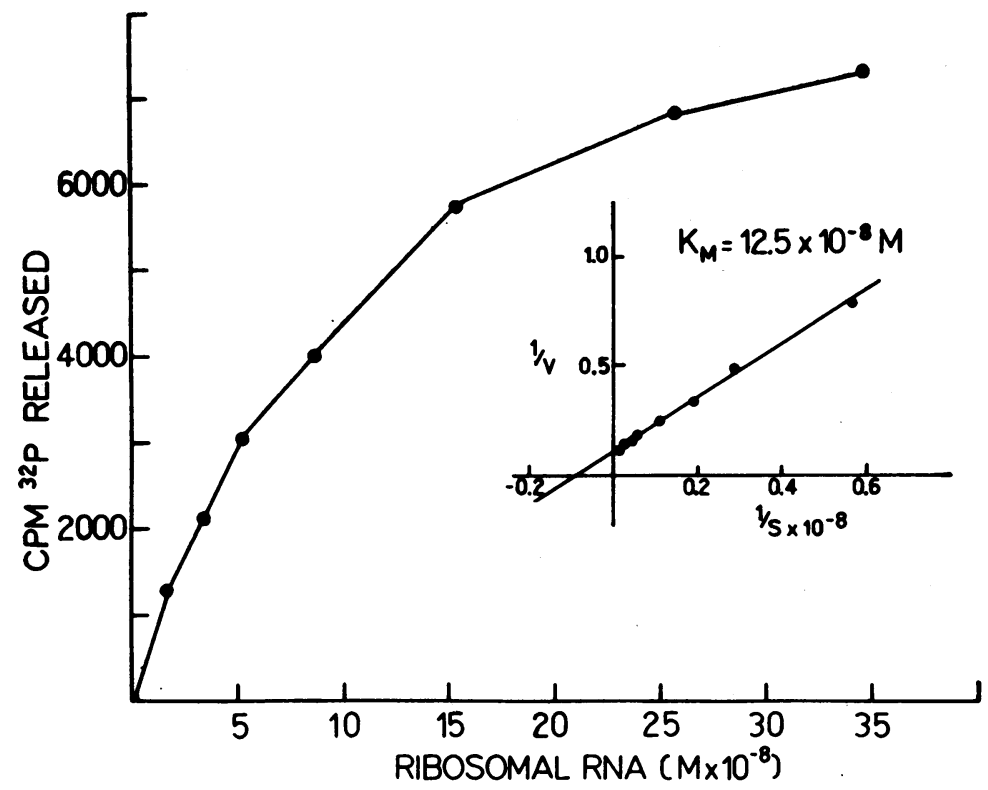

FIGURE 7 The relationship between degradation of RNA by whole lysates and substrate concentration. Assays of whole lysates were carried out over a $30 \mathrm{~min}$ period to insure linearity of the rate of degradation. The inset shows a double reciprocal plot (Lineweaver-Burk) of the data, giving a $K_{m}$ of $12.5 \times 10^{-8} \mathrm{moles} /$ liter for ribosomal RNA. The molecular weight of rRNA was assumed to be $2 \times 10^{8}(15)$.

$37^{\circ} \mathrm{C}$ (Fig. 6). At $-20^{\circ} \mathrm{C}$ approximately $80 \%$ of activity remained after 2 days of storage, and $61 \%$ of the activity was still present on the 15th day of storage.

Kinetics of RNA degradation by whole cell lysates. Fig. 7 shows the relationship between the concentration of substrate and the rate of RNA degradation by whole cell lysates. Incubations in these studies were carried out for only $30 \mathrm{~min}$ to insure linear rates of substrate degradation (see Fig. 2). The rate of degradation asymptotically approaches a maximum as the substrate concentration is increased. A Lineweaver-Burk plot of the data is shown in the inset in Fig. 7. The double reciprocal plot shows that RNA degradation in whole cell lysates follows Michaelis-Menten kinetics. The calculated $K_{m}$ for the substrate used, reticulocyte ribosomal RNA, is $12.5 \times 10^{-8}$ moles/liter. These data, along with the finding that RNA destruction is proportional to the amount of lysate in the assay system (Fig. 1), and the characteristic effect of temperature (11) strongly suggest that an enzyme is responsible for destruction of RNA in whole lysates.

Susceptibility of substrates. The susceptibility of the natural substrates, ribosomal RNA, transfer RNA, and ribosomes to degradation by whole lysates was not similar. Degradation of all substrates followed MichaelisMenten kinetics, and the $K_{m}$ for each of these substrates was determined as illustrated for ribosomal RNA in
Fig. 7 (Table II). To further investigate the susceptibility of the various substrates to enzyme action, approximately equal amounts of the four substrates were placed in assay systems and at intervals during a $2 \mathrm{hr}$ incubation aliquots were removed for determination of acid-soluble fragments of RNA (Fig. 8). Ribosomal RNA was most susceptible to the action of the enzyme. Total RNA, prepared from rabbits with a reticulocytosis of more than $90 \%$, and therefore consisting of

TABLE II

Substrate Kinetics of Whole Lysate RNase

\begin{tabular}{lcccr}
\hline & & \multicolumn{3}{c}{$\begin{array}{c}\text { Rate of substrate } \\
\text { degradation, per } \\
\text { cent per hour } \\
\text { at } 37^{\circ} \mathrm{C}\end{array}$} \\
\cline { 3 - 6 } & $K_{m}$ & & $\mathrm{~N}^{*}$ Per cent & Range \\
\hline Total RNA & $16.7 \times 10^{-8} \mathrm{M}$ & 3 & 21 & $20-21$ \\
Ribosomal RNA & $12.5 \times 10^{-8} \mathrm{M}$ & 6 & 23 & $17-32$ \\
Transfer RNA & $6.1 \times 10^{-6} \mathrm{M}$ & 5 & 9.8 & $6-14$ \\
Ribosomes & $2.0 \times 10^{-6} \mathrm{M}$ & 4 & 5.5 & $1-11$
\end{tabular}

$K_{m}$ of reticulocyte RNA-82P substrates was determined as illustrated in Fig. 7. Rate of substrate degradation was determined during the 1st hour of incubation of studies as illustrated in Fig. 8.

* Number of determinations. 
more than $75 \%$ ribosomal RNA (15), was destroyed at a rate only slightly less than that of isolated ribosomal RNA. Transfer RNA was destroyed at approximately half the rate of that of ribosomal RNA. Intact ribosomes were relatively resistent to degradation by erythroid cell RNase, only $2 \%$ of the labeled rRNA in the particles becoming acid soluble over a $2 \mathrm{hr}$ period. These relative degrees of susceptibility were consistent, as shown by the average rates of destruction of various substrates in several studies (Table II). These results indicate that although isolated ribosomal RNA is quite susceptible to the action of the enzyme, in the form in which it naturally occurs within the cell, organized with protein in ribosomes, it is quite resistent to enzymatic degradation. Deoxyribonucleic acid (DNA) was not broken down upon incubation with erythroid cell lysates.

Although detailed analysis of the products of degradation were not carried out, an estimation of the completeness of RNA degradation in erythroid cell lysates was obtained by comparing the relative amounts of product soluble in 5\% TCA and in uranium salts in TCA. Solutions of uranyl acetate in TCA quantitatively precipitate all compounds larger than nucleotides (19), while some short-chain oligonucleotides, probably containing less than four nucleotides, remain soluble in $5 \%$ TCA (20). Duplicate assays of RNase activity were carried out with various substrates and precipitation was done with a final concentration of either $5 \%$ TCA or $5 \%$ TCA containing $0.25 \%$ uranyl acetate. The proportion of the final degradation products soluble in TCA but insoluble in uranyl acetate, representing oligonucleotides, averaged $6.2 \pm 1.4 \%$ for ribosomal RNA, $26.6 \pm 2.5 \%$ for transfer RNA, and $52.3 \pm 17.6 \%$ for ribosomes. Although this test system does not give detailed data on the size of oligonucleotide fragments, the almost total solubility of degradation products of isolated ribosomal RNA in uranyl acetate indicates that erythroid cell lysates are capable of degrading RNA completely to nucleotides. The lesser degree of complete degradation observed with transfer RNA or ribosomes probably reflects the differences in the rates of degradation of these substrates (see above), and suggests that enzymatic degradation of RNA in the erythroid cell proceeds by steps through a stage of oligonucleotide fragments. It has not been definitely ruled out by these studies that small degration products of ribosomes are coprecipitated with protein by the acid reagents. This appears unlikely, however, since transfer RNA was also not fully degraded and almost half of the total ribosomal degradation did proceed fully to nucleotides.

These studies indicated that substances were present in erythroid cell lysates which degraded both native RNA and ribosomes. To determine whether one enzyme was capable of destroying both RNA and ribosomes, or

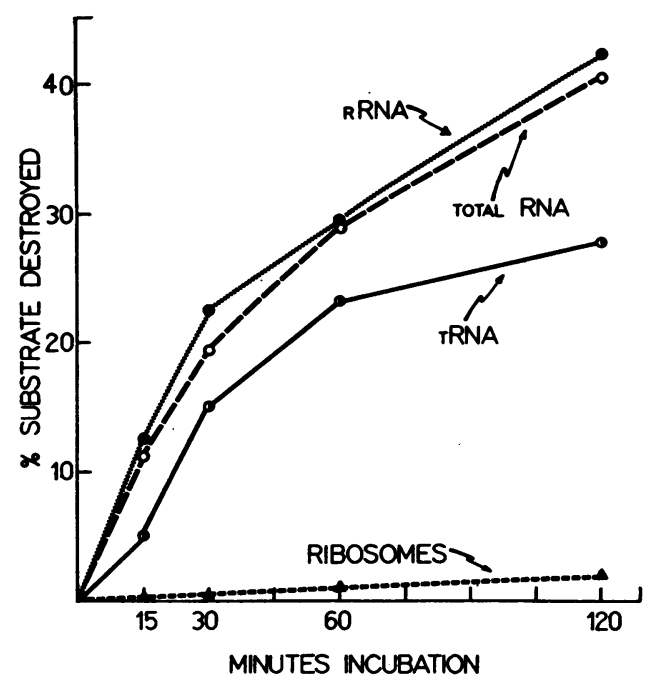

FIgURE 8 Comparison of the rates of degradation of natural substrates by whole lysates. Approximately equal concentrations of substrates were used: ribosomal RNA, $0.13 \mathrm{mg} / \mathrm{ml}$; total $\mathrm{RNA}, 0.15 \mathrm{mg} / \mathrm{ml}$; and transfer RNA, $0.18 \mathrm{mg} / \mathrm{ml}$. The concentration of ribosomes used, $0.3 \mathrm{mg} / \mathrm{ml}$, contains $0.15 \mathrm{mg} / \mathrm{ml}$ of ribosomal RNA.

whether more than one enzyme might be involved, studies were carried out to see if there was competitive inhibition between the substrates in question. RNase activity in cell lysates was assayed against increasing concentrations of $r$ RNA- ${ }^{32} \mathrm{P}$ both in presence and absence of a constant amount of unlabeled ribosomes. The results are shown as Lineweaver-Burk plots in Fig. 9. The $K_{m}$ with rRNA as a substrate, $11.1 \times 10^{-8}$ moles/liter, is in close agreement with that of the separate study shown in Fig. 7. In the presence of ribosomes the intercept on the ordinate is unchanged, but the $K_{m}$ is increased; these findings indicate that there is competitive inhibition between the two substrates. This was confirmed when the study was done using labeled ribosomes as the substrate and unlabeled ribosomal RNA as the inhibitor. Although this indicates that one enzyme system is capable of degrading both native RNA and ribosomes within the erythroid cell, this does not prove that more than one enzyme might not be present.

Effect on ribosomes. Since the bulk of erythroid cell RNA occurs naturally as ribosomes (15) further investigation of the effect of erythroid cell RNase on reticulocyte ribosomes was undertaken. Reticulocyte ribosomes have been reported to contain an RNase $(6,7)$ but this finding has been disputed (8). It was, therefore, first necessary to determine if significant autodegradation of ribosomes occurred during incubation at $37^{\circ} \mathrm{C}$. During a $6 \mathrm{hr}$ incubation at $37^{\circ} \mathrm{C}$ in solution A less than $0.6 \%$ of ${ }^{\circ} \mathrm{P}$-labeled reticulocyte ribosomes were degraded to acid-soluble products. In contrast, ribosomes incubated in 
the presence of whole lysate prepared with the same buffer degraded $7.7 \%$ of their RNA into acid-soluble fragments. This slow rate of degradation was not, however, the only action of erythroid cell RNase on ribosomes. Fig. 10 illustrates that during incubation of reticulocyte ribosomes with whole cell lysates for $30 \mathrm{~min}$ there was virtually complete breakdown of polyribosomes to single ribosomes. The breakdown of polyribosomes occurred after as little as $10 \mathrm{~min}$ incubation. No loss of ribosomal RNA- ${ }^{22} \mathrm{P}$ was detected in this short period. Breakdown of polyribosomes incubated under the same conditions in solution A did not occur, and, in fact, was only minimal after $7 \mathrm{hr}$ of incubation. ${ }^{1}$ It is unlikely that the observed disappearance of polyribosomes was due to continuing protein synthesis, since in the absence of energy protein synthesis does not occur (21). These data indicate that reticulocyte ribosomes do not contain an RNase capable of causing either significant autodegradation or breakdown of polyribosomes, whereas in whole cell lysates there is an enzyme which causes a slow degradation of ribosomes and a rapid conversion of polyribosomes to single ribosomes.

\section{DISCUSSION}

The kinetics of degradation of RNA in erythroid cell lysates indicate that RNA destruction within the mammalian erythroid element is an enzyme-mediated process. Although the lysate system used for the present studies does not provide detailed information relating to an isolated enzyme, the study of RNA degradation under the conditions described demonstrate characteristics of the process applicable to actual in vivo conditions, as opposed to artificial laboratory situations. The charac-

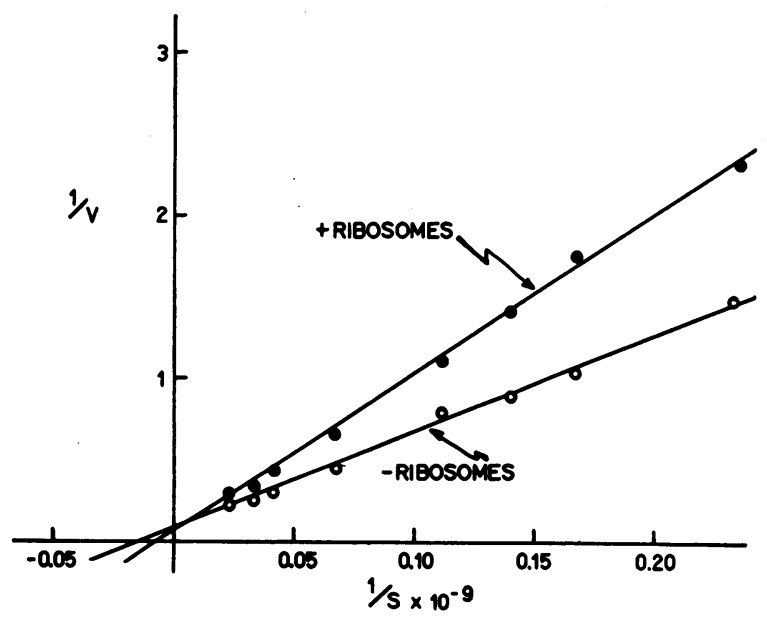

FIGURE 9 Competitive inhibition of degradation of ribosomal RNA by ribosomes. Assays of RNase activity in whole lysates were carried out as described for Fig. 7 in the presence of $1 \mathrm{mg} / \mathrm{ml}$ of unlabeled ribosomes with varying amounts of $r R N A-{ }^{22} \mathrm{P}$ as the substrate.

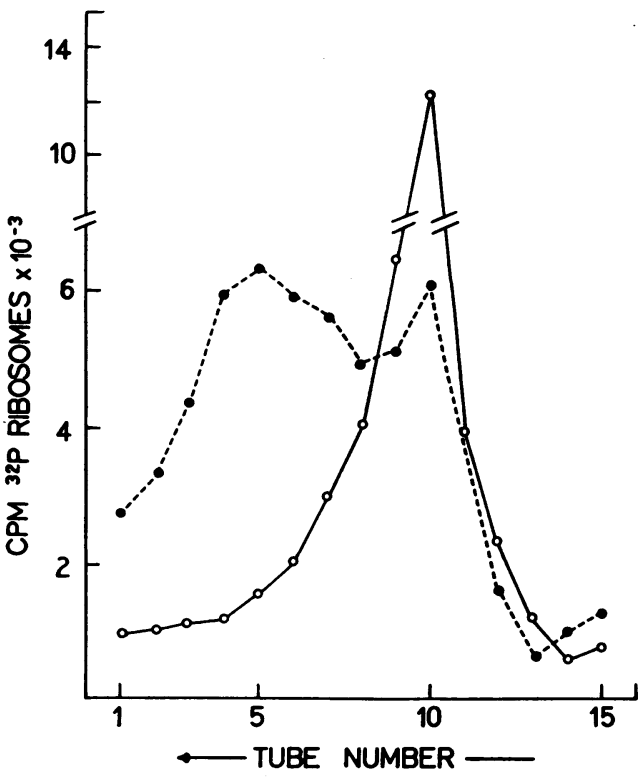

Figure 10 The effect of whole lysate on ribosome structure. Free ${ }^{32} \mathrm{P}$-labeled reticulocyte ribosomes were incubated for $30 \mathrm{~min}$ in either solution A ( $)$ or whole lysate prepared in solution $A(O)$. Equal amounts of the incubation suspensions were layered over an $11.4 \mathrm{ml} 10-30 \%$ linear gradient of sucrose in solution $\mathrm{A}$ and centrifuged at $4^{\circ} \mathrm{C}$ for $1 \mathrm{hr}$ at 40,000 rpm in the Spinco SW 40 rotor. Eight-drop samples were collected directly into vials containing $10 \mathrm{ml}$ of scintillator and counted to determine distribution of ribosomes ${ }^{32} \mathrm{P}$ in the gradient. The direction of sedimentation is from right to left. Tube 10 represents a sedimentation coefficient of $80 \mathrm{~S}$.

teristics of this process strongly suggest that the reticulocyte RNase isolated by Farkas and Marks (3) is responsible for RNA degradation in the erythroid cell. Properties of the enzyme which they isolated from reticulocyte hemolysates which are similar to those of degradation in the lysate system include $\mathrm{pH}$ optimum, the effect of temperature on activity, requirements for and inhibition by ions, ability to break down polyribosomes, and relative insensitivity of enzyme activity to the effects of sulfhydryl donors and inhibitors. This last fact makes it unlikely that oxidation of the enzyme is related to the loss of activity in cell lysates at physiologic temperatures.

Certain differences between the studies in isolated systems and the present ones emphasize the importance of physiologically oriented investigations. Hemoglobin, the major intracellular constituent of the erythroid cell, has been reported to inhibit the action of an RNase purified from erythroid cells in concentrations of 1.2 $\mathrm{mg} / \mathrm{ml}$ (3). In the present studies erythroid cell RNase was active against physiologic concentrations of reticulocyte RNA or ribosomes in the presence of about $50 \mathrm{mg}$ / $\mathrm{ml}$ of hemoglobin. Thus, inhibition by hemoglobin is of little physiologic importance. Heme also inhibits both 
purified erythroid cell RNase (3) and RNase activity in reticulocyte lysates (22). It is unlikely, however, that significant intracellular concentrations of free heme are present in vivo (23).

The evidence, on the basis of solubility of the product in dilute acid solutions of uranyl acetate (19), that degradation of isolated RNA in erythroid cell lysates proceeds fully to nucleotides is consistent with the studies of Bertles and Beck (24). They demonstrated that in the maturing reticulocyte, RNA is completely degraded to low molecular weight products which are metabolized intracellularly or diffuse out of the cell. The partially purified enzyme of Farkas and Marks showed the major product of degradation of liver ribosomal RNA to be acid-soluble oligonucleotides with an average chain length of 6 bases and having a $3^{\prime}$ phosphate terminus (3). If, as the present studies suggest, this endonuclease is responsible for RNA degradation in the intact erythroid cell, phosphodiesterases must be present which further carry the breakdown to completion. The observation that degradation of transfer RNA and ribosomes in erythroid cell lysates proceeds through a stage of short-chain oligonucleotides supports this interpretation. Detailed data concerning phosphodiesterase or monoesterase activity in rabbit erythroid cells is not available.

Farkas and Marks noted that their isolated enzyme degraded transfer RNA at a rate roughly twice that of ribosomal RNA (3). This is in contrast to the results reported here that the reticulocyte lysate system degrades ribosomal RNA more rapidly than transfer RNA. These contradictory results may be due to the use of a different substrate, Escherichia coli transfer RNA, rather than reticulocyte RNA, with the isolated RNase. Despite the rapid rate of degradation of isolated ribosomal RNA in the lysate system, ribosomes were degraded at a relatively slow rate. As the competitive inhibition between ribosomes and rRNA suggests that one enzyme is capable of degrading both substrates, the organization of rRNA in ribosomes must be of importance in determining the susceptibility of the substrate to degradation. Despite the relative resistance of ribosomes to enzymatic degradation, there appears to be a ribosomal RNA component, essential for maintenance of polyribosome structure, which is easily accessible to enzyme action. Whole erythroid cell lysates quickly caused disaggregation of polyribosomes, an action similar to that of minute amounts of pancreatic ribonuclease (21) and RNases extracted from erythroid cells $(3,5)$. The breakdown of polyribosomes to single ribosomes in the presence of cell lysates occurs so rapidly that it suggests that intracellular mechanisms may be present which, by balancing RNase activity, maintain a concentration of polyribosomes sufficient to support necessary protein synthesis. An inhibitor of ribonuclease has been isolated from rabbit reticulocytes (25).

The finding that the rate of degradation of ribosomes in the lysate system was less than that of soluble RNA was unexpected, since during in vivo maturation of intact erythroid cells ribosomes disappear at a rate greater than that of soluble RNA (11). The discrepancy between the relative rates of degradation of ribosomes and soluble RNA in vitro and in vivo suggests that there is a specific mechanism within the cell which regulates the rate of ribosome degradation. One such mechanism to be considered is that ribosomes themselves contain an RNase, but the present studies confirmed the absence of significant RNase activity in ribosomes (8). The relatively rapid degradation of reticulocyte ribosomes in vivo, in comparison with soluble RNA, thus cannot be ascribed to an inherent ribosomal RNase. Although the significance of binding of ribosomes to cell membranes remains unknown, it is possible that this plays a part in ribosome degradation. Two studies have suggested that the major portion of erythroid cell RNase is confined to the cell membrane $(4,5)$, and the erythroid cell membrane is, in itself, capable of degrading endogenous RNA (11).

The nature of the association between decreasing RNA content and erythroid cell maturation remains obscure. High concentrations of magnesium have been reported to retard reticulocyte maturation (26). The observation that magnesium ions inhibit erythroid cell RNase in cell lysates suggests, but does not prove, the possibility that RNase activity is involved in cell maturation. Reticulocyte maturation has also been reported to be slowed by inhibitors of glycolysis (27). The present work, however, showed no effect by inhibitors of glycolysis on RNase activity in erythroid cell lysates. Further studies of erythroid RNA degradation in a system oriented toward physiologic conditions, presently in progress, may clarify this relationship, and further elucidate the role of the cell membrane in erythroid cell RNA metabolism.

\section{ACKNOWLEDGMENT}

This investigation was supported by U. S. Public Health Service Grants HE-10473 and H-6374.

\section{REFERENCES}

1. Grasso, J. A., J. W. Woodard, and H. Swift. 1963. Cytochemical studies of nucleic acids and proteins in erythrocytic development. Proc. Nat. Acad. Sci. U. S. A. 50: 134.

2. Marks, P. A., E. R. Burka, and D. Schlessinger. 1962. Protein synthesis in erythroid cells. I. Reticulocyte ribo- 
somes active in stimulating amino acid incorporation. Proc. Nat. Acad. Sci. U. S. A. 48: 2163.

3. Farkas, W., and P. A. Marks. 1968. Partial purification and properties of a ribonuclease from rabbit reticulocytes. J. Biol. Chem. 243: 6464.

4. Lindigkeit, R. 1956. Die nucleasewirksamkeit in den Reticulocyten von kaninchen. Folia Haematol. (Leipzig). 74: 251 .

5. Adachi, K., K. Nagano, T. Nakao, and M. Nakao. 1964. Purification and characterization of ribonuclease from rabbit reticulocytes. Biochim. Biophys. Acta. 92: 59.

6. Farkas, W. R., M. Singer, and P. A. Marks. 1964. Nuclease of rabbit reticulocyte ribosomes. Fed. Proc. 23: 220.

7. Mathias, A. P., R. Williamson, H. E. Huxley, and S. Page. 1964. Occurrence and function of polysomes in rabbit reticulocytes. J. Mol. Biol. 9: 154.

8. Stavy, L., M. Feldman, and D. Elson. 1964. On ribonuclease activity in reticulocyte ribosomes. Biochim. Biophys. Acta. $91: 606$.

9. Rowley, P. T., and F. Barnes. 1966. A reticulocyte RNase activity declining with cell maturation. Fed. Proc. 25: 645.

10. Rowley, P. T., and J. A. Morris. 1967. Protein synthesis in the maturing reticulocyte. J. Biol. Chem. 242: 1533.

11. Burka, E. R. Characteristics of RNA degradation in the erythroid cell. J. Clin. Invest. 48: 1266.

12. Schreml, W., and E. R. Burka. 1968. Properties of membrane-bound ribosomes in reticulocytes. J. Biol. Chem. 243: 3573.

13. Swan, H., and A. W. Nelson. 1968. Canine trapped plasma factors at different microhematocrit levels. $J$. Surg. Res. 8: 551.

14. DeBellis, R. H., N. Gluck, and P. A. Marks. 1964. Synthesis of ribonucleic acid in rabbit blood cells in vivo. J. Clin. Invest. 43: 1329.
15. Burka, E. R. 1968. The distribution of RNA and ribosomes in reticulocytes. Biochim. Biophys. Acta. 166: 672 .

16. Burka, E. R. 1966. Determination of ribosenucleic acid in nonnucleated erythroid cells. J. Lab. Clin. Med. 68: 833.

17. Bray, G. A. 1960. A simple, efficient liquid scintillator for counting aqueous solutions in a liquid scintillation counter. Anal. Biochem. 1: 279.

18. Fraenkel-Conrat, H., B. Singer, and A. Tsugita. 1961. Purification of viral RNA by means of bentonite. Virology. 14: 54.

19. MacFadyen, D. A. 1934. The nuclease activity of bacillus subtilis. J. Biol. Chem. 107: 297.

20. Miller, Z. B., and L. M. Kozloff. 1947. The ribonuclease activity of normal and parasitized chick erythrocytes. J. Biol. Chem. 170: 105.

21. Warner, J. R., P. M. Knopf, and A. Rich. 1963. A multiple ribosomal structure in protein synthesis. Proc. Nat. Acad. Sci. U. S. A. 49: 122.

22. Burka, E. R. 1968. Hemin: an inhibitor of erythroid cell ribonuclease. Science (Washington). 162: 1287.

23. Allen, D. W., and J. H. Jandl. 1960. Kinetics of intracellular iron in rabbit reticulocytes. Blood. 15: 71 .

24. Bertles, J. F., and W. S. Beck. 1962. Biochemical aspects of reticulocyte maturation. I. Fate of the ribonucleic acid. J. Biol. Chem. $237: 3770$.

25. Priess, V. H., and W. Zillig. 1967. Inhibitor für pankreatische Ribonuclease aus roten blutzellen. HoppeSeyler's Z. Physiol. Chem. 348: 817 .

26. Pepper, O. H. P. 1922. Observations on vitally-stainable reticulation and chromatic granules in erythrocytes preserved in vitro. Arch. Intern. Med. 30: 801.

27. Nizet, A. 1946. Influence du glucose, des extraits de foie, de la thyroxine, de l'urethane et du cyanure de potassium sur la maturation reticulocytaire. C. R. Seances Soc. Biol. Filiales. 140: 1076. 